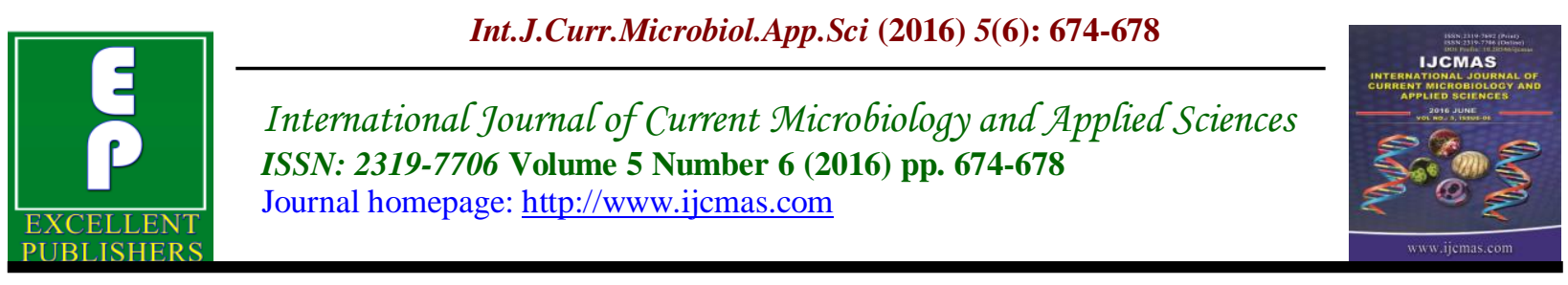

Original Research Article

http://dx.doi.org/10.20546/ijcmas.2016.506.073

\title{
Assessment of Genetic Diversity by Using RAPD Markers of Vigna unguiculata cultivars in Telangana State, India
}

\author{
A. Srujana* and N. Lakshmi Bhavani \\ Plant Tissue Culture and Plant Molecular Genetics Lab, Department of Botany, University \\ College of science, Saifabad, Osmania University, Hyderabad.500004, India \\ *Corresponding author
}

\begin{tabular}{|c|c|}
\hline & A B S T R A C T \\
\hline $\begin{array}{l}\text { Cowpea, } \\
\text { Vigna unguiculata, } \\
\text { Genetic Diversity } \\
\text { RAPD Markers, } \\
\text { Dendrogram, }\end{array}$ & \multirow{3}{*}{$\begin{array}{l}\text { In the present study genetic diversity based on RAPD markers was carried for five } \\
\text { high yielding cultivars of Vigna unguiculata from Telangana region. A total } 16 \\
\text { primers were used for the detection of polymorphism. Out of } 230 \text { bands formed } \\
109 \text { bands were found to be polymorphic. However the extent of polymorphism } \\
\text { varied with each primer present and an average of } 91.1 \% \text { polymorphism was found } \\
\text { among the cultivars in Vigna. Dendrogram constructed based on UPGMA analysis } \\
\text { showed two clusters with first cluster bifurcating into two subclusters a and b. } \\
\text { Dendrogram and similarity index clearly indicated that Gangothri and Pusakomal } \\
\text { are in the same cluster a, and two cultivars Navrathan and Gowthami in cluster b,of } \\
\text { the first cluster representing two genetically similar groups. Gomchi found to be } \\
\text { genetically much distant and formed a second cluster indicating that this cultivar is } \\
\text { much variant from others. }\end{array}$} \\
\hline Ar & \\
\hline $\begin{array}{l}\text { Accepted: } \\
24 \text { May } 2016 \\
\text { Available Online: } \\
10 \text { June } 2016\end{array}$ & \\
\hline
\end{tabular}

\section{Introduction}

Cowpea is also commonly referred to as southern pea or black-eyed pea. Cowpea is one of several species of the widely cultivated genus vigna. It is chiefly used as a grain crop; for animal fodder, or as a vegetable. Cowpea is one of the principal pulses of common use in India. The crop appears to have spread from India to china and other south East Asian countries. Vavilov (1939) recognized India as the main centre of origin of this crop. Cowpea is particularly valuable component of low input farming systems of resource for poor farmers because of its productivity and ability of the crop to enhance soil fertility for succeeding cereal grown on rotation.
The present study was undertaken to evaluate the pattern and existence of genetic variability and relatedness among cultivars for genetic improvement of cowpea using RAPD markers. RAPD (Random Amplified polymorphic DNA) analysis can be used to characterize DNA variation patterns within species and among closely related taxa (Williams et al.,1990).Within grain legume crops alone, RAPD markers have been widely used for the identification of genetic relationships among cultivars (Sonnante and Pignone 2001); among wild forms (Freyre et al.,1996; Cattan-Toupance et al.,1998), or between cultivars and wild forms (Mimura et al., 2000; Raina et al 2001).To date, few 
studies have been performed in cowpea using RAPDs (Menendez et al., 1997; Mignouna et al., 1998 ).In 2004 Fana Sylla and Paul have reported genetic diversity in cowpea (Vigna unguiculata) as revealed by RAPD markers. To characterize DNA variation patterns among closely related taxa and within species in Vigna, RAPD (Dikshit et al., 2007) and SSRs (Dikshit et al., 2007) have been adopted.

\section{Materials and Methods}

The plant material used in the present study consisted of five cultivars of cowpea (Navrathna, Pusakomal, Gnagothri, Gowthami, and Gomchi) collected from National Seeds Corporation, Hyderabad, Telangana. Genomic DNA from vigna unguiculata leaves was extracted with the modified CTAB (Cetyl Tri Methyl Ammonium Bromide) method (Saghaimaroof et al., 1984). About 150-300mg of fresh leaf sample was surface sterilized and crushed with $2 \mathrm{XCTAB}$ extraction buffer with $2 \%$ PVP and $10 \mathrm{mM}$ of $\beta$ mercaptoethanol (Doyle and Doyle1987). Sample is collected in $1.5 \mathrm{ml}$ tube and incubated at $65^{\circ} \mathrm{C}$ for 30 minutes in a water bath and mixed gently with swirling. To these tubes equal volume of Chloroform: Iso-amyl alcohol (24:1) are added and mixed properly. The tubes were centrifuged at $8000 \mathrm{rpm}$ for 15 minutes. The final aqueous layer was transferred to a centrifuge tube and equal volume of chilled isopropanol is added and mixed thoroughly. This is incubated at $-20^{\circ} \mathrm{C}$ for 1 hour and centrifuged at $8000 \mathrm{rpm}$ for $15 \mathrm{~min}$. The supernatant is discarded and the pellet is air dried for overnight. The pellet is resuspend in 30-50 $\mu 1 \mathrm{TE}$ buffer. The sample is incubated at $60^{\circ} \mathrm{C}$ for 1 hour and stored at $0^{\circ} \mathrm{C}$ for further use.
DNA samples were first suspended in 100 $\mathrm{ml}$ of tris EDTA buffer and then diluted to 4 $\mathrm{ng} / \mu \mathrm{l}$ with water. The PCR reaction mixture, contained a total reaction volume of $25 \mu 1$, including $32 \mathrm{ng}$ of template DNA, $\mathrm{Mgcl}_{2}$ to a final concentration of $1.9 \mathrm{mM}, 25 \mathrm{mM}$ of each Dntps and 33 ng of decamer primer (Bioserve, India). DNA sequences were amplified using eppendorff thermo cycler. The parameters of the PCR cycle were as follows: 1 cycle at $94^{\circ} \mathrm{c}$ for $2 \mathrm{~min}$ : 40 cycles of $94^{\circ} \mathrm{c}$ for $1 \mathrm{~min}, 35^{\circ} \mathrm{c}$ for $1 \mathrm{~min}$ and $72^{\circ} \mathrm{c}$ for $2 \mathrm{~min}$ : 1 cycle at $72^{\circ} \mathrm{c}$ for $5 \mathrm{~min}$; and 1 cycle at $30^{\circ} \mathrm{c}$ for $30 \mathrm{~min}$. After amplification, $3 \mu \mathrm{l}$ of gel loading buffer was added to each sample. A sample of $10 \mu \mathrm{l}$ of PCR product was separated by electrophoresis at 100 volts and stained with $(0.5 \mu \mathrm{l}$ ethidium bromide per $\mathrm{ml}$ of buffer) before visualizing the banding patterns under UV light and scanning the images. A $1.5 \mathrm{~kb}$ DNA ladder was used for sizing the RAPD bands. Primers were selected from those chosen by Menendez et al (1997) out of a total of 16 primers.

\section{Results and Conclusion}

Genomic DNA was extracted from five different cultivars of vigna. A total of 12 primers were used for RAPD analysis in vigna cultivars. Among 12 primers, four primers did not show any amplification, 4 primers showed only monomorphic bands, four primers OPA -1, OPA -4, OPB- 10, OPB- 15 showed polymorphism in all the samples, however the extent of polymorphism varied with each primer. A total of 230 loci (109 polymorphic ranging between 100-1350bp) were amplified. On an average a total polymorphism percent in vigna was recorded as $91.1 \%$ among the cultivars under study. 
Table.1 List of 4 RAPD primers, polymorphism and banding patterns of genotypes of Vigna

\begin{tabular}{|l|l|l|l|l|l|l|l|l|l|l|}
\hline Primer name & Primer Sequence & TM & GC & Max.B & TB & PB & MB & $\%$ P & Range of band & PIC. \\
\hline OPA1 & CAGGCCCTTC & 32 & $60 \%$ & 8 & 17 & 16 & 1 & 94.1 & $150-1350 \mathrm{bp}$ & 0.8 \\
\hline OPA4 & AATCGGGCTG & 32 & $60 \%$ & 11 & 31 & 28 & 3 & 90.3 & $150-600 \mathrm{bp}$ & 0.664 \\
\hline OPA10 & GTGATCGCAG & 32 & $60 \%$ & 13 & 40 & 36 & 4 & 90 & $200-1200 \mathrm{bp}$ & 0.7532 \\
\hline OPA15 & TTCCGAACCC & 32 & $60 \%$ & 13 & 32 & 29 & 3 & 90 & $100-1350 \mathrm{bp}$ & 0.598 \\
\hline
\end{tabular}

Fig.1 RAPD PCR based polymerase chain reaction fingerprints pattern for genomic DNA of Vigna genotypes from the Telengana State.

L: LADDER G1: GANGOTHRI G2: PUSA G3: NAVRATHAN G4: GOWTHAMI G5:

\section{GOMCHI}
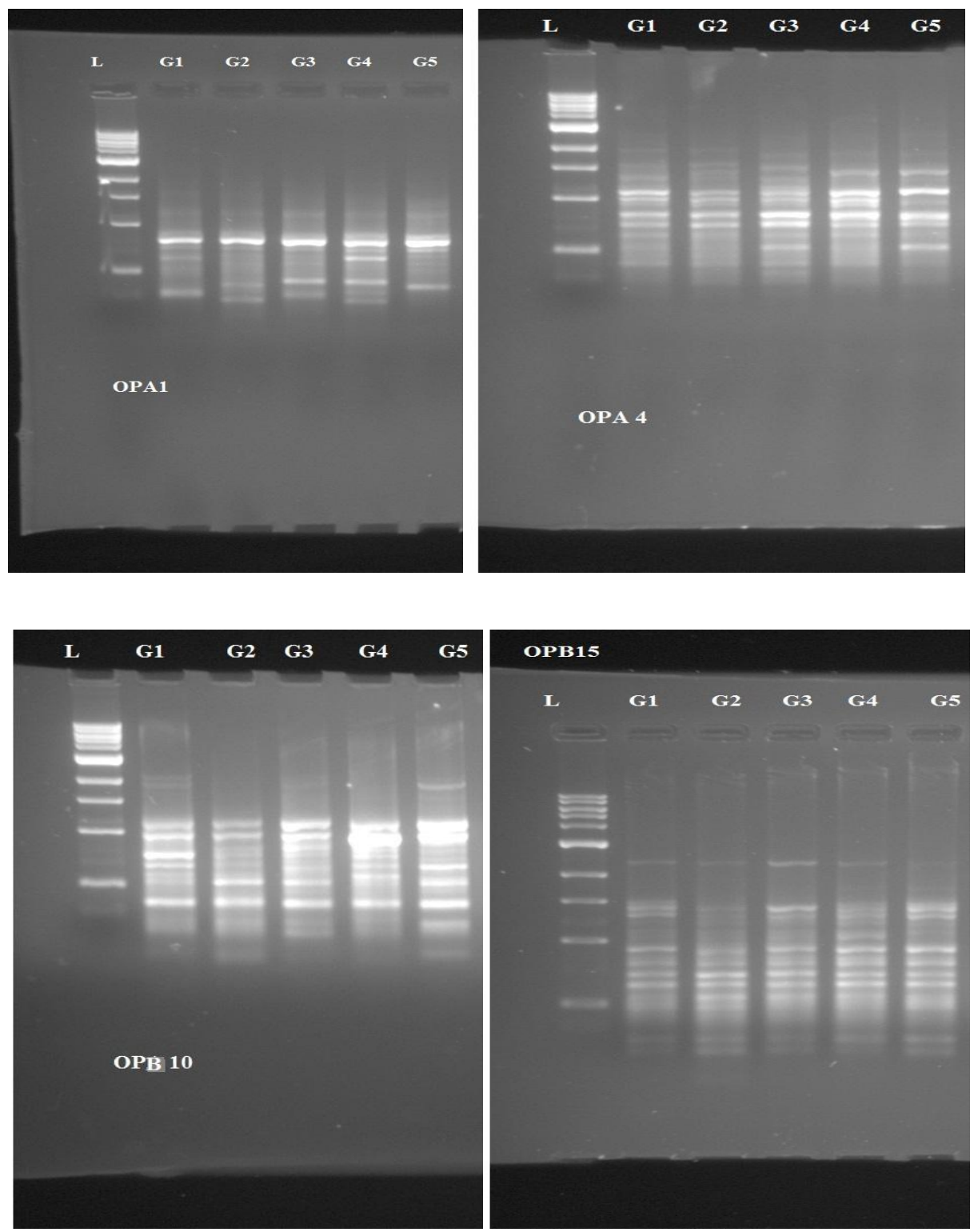
Fig.2 UPGMA deprogram showing relatedness among the different local cultivars of vigna using RAPD primers.

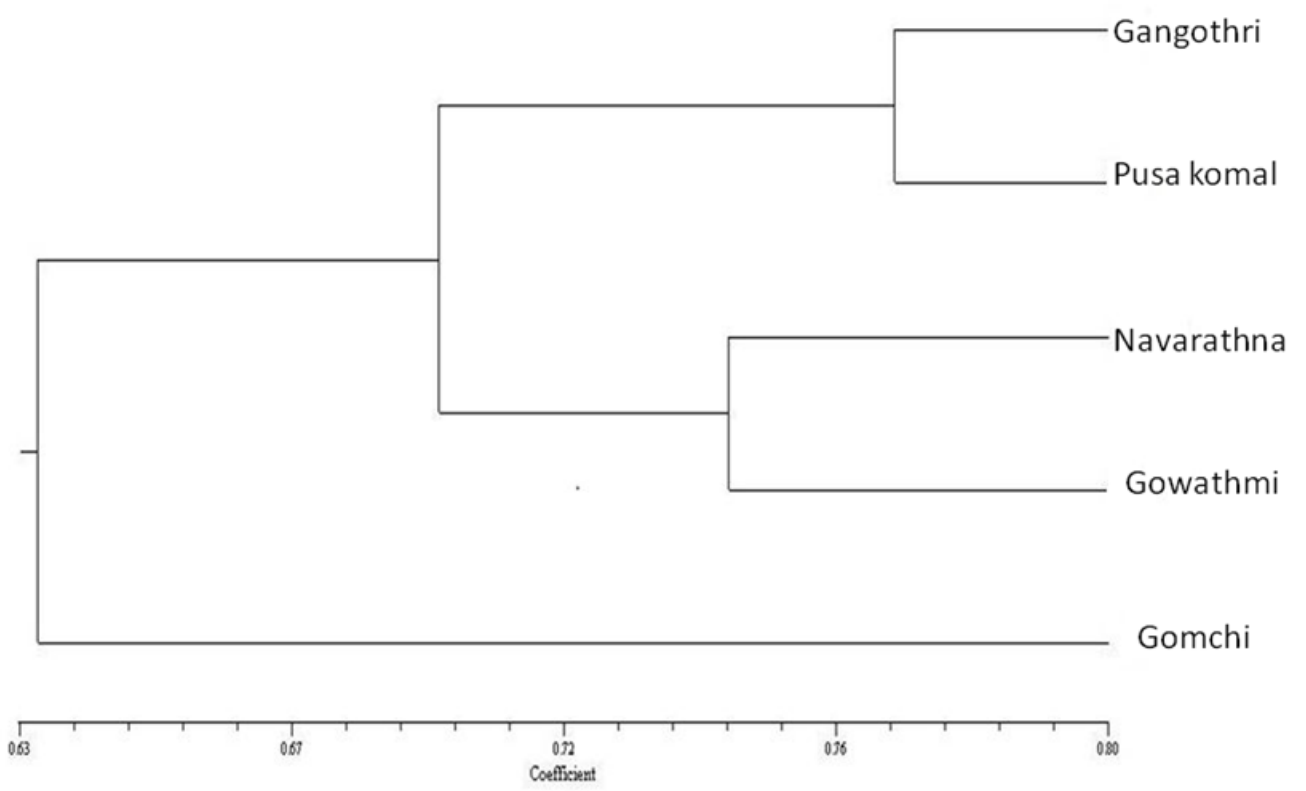

Fig.3 Table.3: Dice coefficients of similarity based on RAPDs showing the relationship between Vigna cultivars

Gangothri Navarathna Pusakomal Gowthami Gomchi

Gngothri $\quad 1.0000000$

Navarathna $\quad 0.7000000 \quad 1.0000000$

Pusakomal $0.7666667 \quad 0.7142857 \quad 1.0000000$

$\begin{array}{lllll}\text { Gowthami } & 0.6774194 & 0.7407407 & 0.6896552 & 1.0000000\end{array}$

$\begin{array}{llllll}\text { Gomchi } & 0.6774194 & 0.6206897 & 0.6333333 & 0.6000000 & 1.0000000\end{array}$

Polymerase chain reaction (PCR) based markers using arbitrary primers, such as RAPD, have been widely used for investigating Gene relatedness and diversity in plant population and cultivars. Markers are polymorphic in nature. DNA-based markers can be applied for this purpose because they can be used for assessing precisely the genotype of a plant. Several DNA marker systems are now commonly used in diversity studies of plants.

Based on UPGMA (un-weighted pair group of arithmetic means) analysis, dendrogram was constructed. This Dendrogram and similarity index clearly indicates the presence of two main clusters, cluster $\mathbf{1}$ and cluster 2.Cluster $\mathbf{1}$ is sequential cluster. It is further divided into cluster $\mathbf{a}$ and cluster b.Cluster a contains two cultivars Gangothri and pusakomal, these are genetically similar with a genetic distance of 0.77 . Cluster b contain two cultivars Navratan and Gowthami that are genetically similar, with genetic distance of 0.74 . Cluster 2 with only Gomchi cultivar is genetically much variant from both clusters, cluster a and Custer $\mathbf{b}$, with genetic distance of 0.80 indicating that 
Gomchi is genetically much variant from other cultivars.

\section{References}

Cattan-Toupance, I., Michalakis, Y., Neema, C. 1998. Genetic structure of wild bean populations in their south-andean centre of origin. Theor. Appl. Genet., 96: 844851.

Dikshit, H.K., Jhang, T., Singh, N.K., Koundal, K.R., Bansal, K.C., Chandra, N., Tickoo, J.L. and Sharma, T.R. 2007. Genetic differentiation of Vigna species by RAPD, URP and SSR markers. Biologial plantarum., 51(3): 451-457.

Doyle, J.J., Doyle, J.L. 1987. A rapid DNA isolation procedure for small quantities of fresh leaf tissue. Phytochem. Bull., 19: 11-15.

Fana Sylla, Pasquet, R.S., Paul, G. 2004. Genetic diversity in cowpea (Vinga unguiculata (L.) Walp.) as revealed by RAPD markers, Genetic resources and crop evolution., 51: 539-550.

Freyre, R., Rios, R., Guzman, L., Debouck, D. and Gepts, P. 1996 Ecogeographic distribution of Phaseolus spp. (Fabaceae) in Bolivia. Econ. Bot., 50: 195-215.

Menendez, C.M., Hall, A.E. and Gepts, P. 1997. A genetic linkage map of cowpea (Vigna unguiculata) developed from a cross between two inbred domesticated lines. Theor. Appl. Genet., 95: 1210 1217.

Mignouna, H.D., Ng, N.Q., Ikea, J. and Thottappilly, G. 1998. Genetic diversity in cowpea as revealed by random amplified polymorphic DNA. J. Genet. Breed., 52: 151-159.

Mimura, M., Yasuda, K. and Yamaguchi, H. 2000. RAPD variation in wild, weedy and cultivated azuki beans in Asia. Genet. Resour. Crop Evol., 47: 603-610.

Raina, S.N., Rani, V., Kojima, T., Ogihara, Y., Singh, K.P. and Devarumath, R.M. 2001. RAPD and ISSR fingerprints as useful genetic markers for analysis of genetic diversity, varietal identifi- cation, and phylogenetic relationships in peanut (Arachis hypo- gaea) cultivars and wild species. Genome, 44: 763-772.

Saghai-Maroof, M.A., Soliman, K.M., Jorgensen, R.A., Allard, R.W. 1984. Ribosomal DNAsepacer-length polymorphism in barley: mendelian inheritance, chromosomal location, and population dynamics. Proc. Natl. Acad. Sci., 81: 8014-8019.

Sonnante, G., Pignone, D. 2001. Assessment of genetic variation in a collection of lentil using molecular tools. Euphytica, 120: 301-307.

Vavilov, N.I. 1939. Address at a Conference on Genetics and Selection; in: Science and Life (a Soviet Magazine). (Mimeographed translation from a former U. S. Government official.)

Williams, J.G.K., Kubelik, A.R., Livak, K.J., Rafalski, J.A. and Tinigey, S.V. 1990. DNA polymorphisms amplified by arbitrary primers are useful as genetic markers. Nucl. Acids Res., 18: 65316535 .

\section{How to cite this article:}

Srujana, A., and Lakshmi Bhavani, N. 2016. Assessment of Genetic Diversity by Using RAPD Markers of Vigna unguiculata cultivars in Telangana State, India. Int.J.Curr.Microbiol.App.Sci. 5(6): 674-678. doi: http://dx.doi.org/10.20546/ijcmas.2016.506.073 